\title{
MEF2D wt Allele
}

National Cancer Institute

\section{Source}

National Cancer Institute. MEF2D wt Allele. NCI Thesaurus. Code C92165.

Human MEF2D wild-type allele is located within 1q12-q23 and is approximately $37 \mathrm{~kb}$ in length. This allele, which encodes myocyte-specific enhancer factor 2D protein, is involved in the modulation of transcription during muscle development and neuronal differentiation. 